University of South Carolina

Scholar Commons

2016

Sovereign Impunity: Why Double Jeopardy Should Apply in Puerto

Rico

Colin Miller

University of South Carolina - Columbia, mille933@law.sc.edu

Follow this and additional works at: https://scholarcommons.sc.edu/law_facpub

Part of the Law Commons

Recommended Citation

Colin Miller, Sovereign Impunity: Why Double Jeopardy Should Apply in Puerto Rico, 73 WASH. \& LEE L. REV. ONLINE 174 (2016).

This Article is brought to you by the Law School at Scholar Commons. It has been accepted for inclusion in Faculty Publications by an authorized administrator of Scholar Commons. For more information, please contact digres@mailbox.sc.edu. 


\title{
Sovereign Impunity: Why Double Jeopardy Should Apply in Puerto Rico
}

\author{
Colin Miller*
}

\begin{abstract}
On January 13th, 2016, the Supreme Court of the United States heard oral arguments in Puerto Rico v. Sanchez Valle. The question that the Court must decide is whether the federal government and the Commonwealth of Puerto Rico are separate sovereigns for purposes of the Double Jeopardy Clause. This essay argues that the Supreme Court cannot answer this question in the affirmative without overturning precedent holding that the U.S. government can unilaterally impose the Federal Death Penalty Act in Puerto Rico. In other words, the Court cannot deprive Puerto Rican citizens of the protection of the Double Jeopardy Clause unless it adopts the concept of popular sovereignty.
\end{abstract}

\section{Table of Contents}

I. Double Jeopardy and Dual Sovereignty 175

II. The Death Penalty in Puerto Rico: Popular Sovereignty vs. Dual Sovereignty

III. The Tenth Amendment and Dual Sovereignty....

IV. Conclusion

There is no disagreement that Congress has the power to apply the federal criminal laws to Puerto Rico. With that power, of necessity, comes the power to set the penalties for violations of those laws. Indeed, it would be anomalous for

* Professor and Associate Dean for Faculty Development, University of South Carolina School of Law; Blog Editor, EvidenceProf Blog. http://lawprofessors.typepad.com/evidenceprof/. 
Congress to grant the people of Puerto Rico American citizenship and then not afford them the protection of the federal criminal laws. ${ }^{1}$

\section{Double Jeopardy and Dual Sovereignty ${ }^{2}$}

The Double Jeopardy Clause of the Fifth Amendment states: "nor shall any person be subject for the same offense to be twice put in jeopardy of life or limb." Jeopardy attaches when the jury is empaneled and sworn, or, at a bench trial, when the first witness is sworn. ${ }^{4}$ After jeopardy attaches, a defendant cannot be re-prosecuted for the same act unless (1) there is "manifest necessity for declaring a mistrial," such as a hung jury; ${ }^{5}$ or (2) the defendant is charged with violating a different statute at his second trial, with the statutes at each trial both requiring "proof of a fact which the other does not."6

In Puerto Rico v. Sanchez Valle, ${ }^{7}$ Puerto Rican prosecutors charged Luis Sánchez Valle and Jaime Gómez Vázquez with violating Commonwealth law by selling firearms-and, in the case of Sánchez Valle, ammunition-without a license. ${ }^{8}$ Before these cases went to trial, the two men were convicted in United States District Court based upon the same conduct. ${ }^{9}$ The men

1. United States v. Acosta Martinez, 252 F.3d 13, 21 (2001).

2. After this essay was written, the Supreme Court issued its opinion in Sanchez Valle. In her majority opinion, Justice Kagan wrote that

[F]or purposes of the Double Jeopardy Clause, the future is not what matters-and there is no getting away from the past. Because the ultimate source of Puerto Rico's prosecutorial power is the Federal Government-because when we trace that authority all the way back, we arrive at the doorstep of the U.S. Capitol-the Commonwealth and the United States are not separate sovereigns. That means the two governments cannot "twice put" respondents Sánchez Valle and Gómez Vázquez "in jeopardy" for the "same offence."

Puerto Rico v. Sanchez Valle, No. 15-108, slip op. at 17-18 (S. Ct. June 9, 2016).

3. U.S. Const. amend. V.

4. Willhauck v. Flanagan, 448 U.S. 1323, 1326-27 (1980).

5. Arizona v. Washington, 434 U.S. 497, 500 (1978).

6. Blockburger v. United States, 284 U.S. 299, 304 (1932).

7. 192 D.P.R. 594 (P.R. 2015), cert. granted, 136 S. Ct. 28 (2015) (certified translation).

8. See id. at 2 a (recounting the facts of the case and the charges).

9. Id. at $2 \mathrm{a}-3 \mathrm{a}$. 
then moved to dismiss their Puerto Rican prosecutions, claiming that they violated their rights under the Double Jeopardy Clause. ${ }^{10}$

The Commonwealth court agreed. ${ }^{11}$ On appeal, however, the Court of Appeals of Puerto Rico reversed, finding that the dual sovereignty doctrine applied. ${ }^{12}$ That doctrine provides that a defendant who committed a single act violating the "peace and dignity" of two sovereigns has committed two distinct "offences." 13 Therefore, if a defendant's single act violates the laws of two countries, such as France and the United States, he could be prosecuted in both countries successively without violating the Double Jeopardy Clause. ${ }^{14}$ Similarly, an act that breaks both federal and state law would allow for prosecutions in both federal and state court. ${ }^{15}$ The same holds true for a defendant who is court-martialed and then charged in state court or vice versa. ${ }^{16}$

Conversely, a defendant convicted or acquitted in federal court could not be court-martialed for the same conduct because military courts derive their authority from the federal government. ${ }^{17}$ The "crucial determination" in deciding whether the dual sovereignty doctrine applies "is whether the two entities

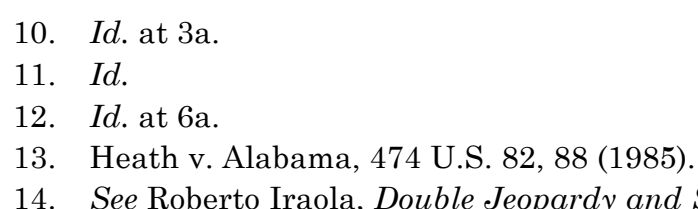

14. See Roberto Iraola, Double Jeopardy and Sovereignty, 47 CRIM. L. BULL. Art. 6 (2011) ("[T]he dual sovereignty doctrine applies to allow serial prosecutions involving the same offense by a foreign country and the United States ....”).

15. See, e.g., Jim Mustian, Man Acquitted of a New Orleans Murder in Federal Court Wanted on State Warrant Stemming from Same Killing, NEW $\begin{array}{llllll}\text { ORLEANS ADVOC. } & \text { (May 28, 2015, } & 7: 57 & \text { PM), }\end{array}$ http://www.theneworleansadvocate.com/news/12495659-123/man-acquitted-ofmurder-in (last visited May 30, 2016) (discussing the case of Ryan J. Veazie, who is wanted in New Orleans on one count of second-degree murder but was already tried and acquitted of that crime in district court in 2008) (on file with the Washington and Lee Law Review).

16. See, e.g., United States v. Stokes, 12 M.J. 229, 229 (C.M.A. 1982) (“A general court-martial convened in Spain convicted the appellant, contrary to his please, of wrongful sale... of hashish and of conspiracy to make that sale ....").

17. See id. at 231 (noting that "trial by a court-martial is barred by the [Uniform] Code [of Military Justice] ... if the accused has already been tried in a court which derives its authority from the Federal Government"). 
that seek successively to prosecute a defendant for the same course of conduct can be termed separate sovereigns." 18 In resolving this "crucial determination," courts look to "whether the two entities draw their authority to punish the offender from distinct sources of power."19

While the Commonwealth court answered this question in the affirmative in Puerto Rico v. Sanchez Valle, the Court of Appeals of Puerto Rico disagreed, noting that the Supreme Court of Puerto Rico had already held in People v. Castro García ${ }^{20}$ that Puerto Rico and the federal government are separate sovereigns for Double Jeopardy purposes. ${ }^{21}$ Moreover, Judge González Vargas wrote separately to emphasize that the authority for Puerto Rico's criminal laws "emanates...from the People of Puerto Rico through their Constitution, which was democratically adopted as the ultimate expression of their will in the exercise of their self-government attributes." ${ }^{22}$ According to the judge:

It is legally unacceptable and contrary to the dignity of every Puerto Rican to argue that even the adoption of their criminal laws and the indictment for the violation of same are merely the result of gifts or graces by the People of the United States, as if we found ourselves in the times of the crudest colonial regime. ${ }^{23}$

The Supreme Court of Puerto Rico, however, disagreed, repudiating its prior opinion in Castro Garcia as "clearly erroneous."24 A sharply divided court concluded that "Puerto Rico's authority to prosecute individuals is derived from its delegation by United States Congress and not by virtue of its own sovereignty." 25 As such, the Double Jeopardy Clause applied and the dual sovereignty doctrine did not. ${ }^{26}$

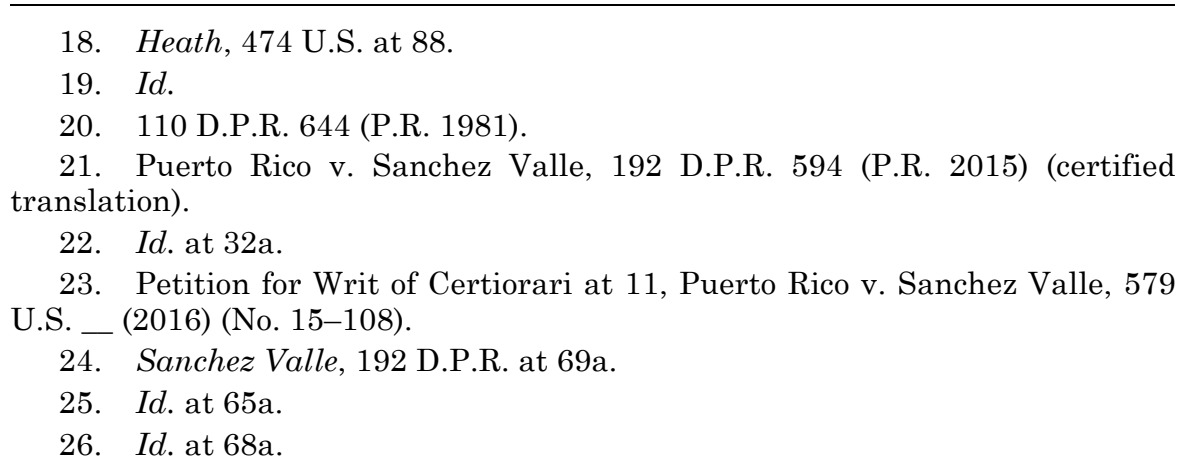


During oral argument before the Supreme Court, the attorney for the Commonwealth of Puerto Rico argued against this conclusion, claiming that

a prior Federal conviction has no Double Jeopardy implications for the enforcement of the Commonwealth's criminal laws because Commonwealth law and Federal law emanate from different sources of authority: The people of Puerto Rico on the one hand and Congress on the other. ${ }^{27}$

It's not the first time that this argument has been made.

\section{The Death Penalty in Puerto Rico: Popular Sovereignty vs. Dual Sovereignty}

Between 1493 and 1898, Puerto Rico was a Spanish colony, and Spanish authorities regularly imposed the death penalty to control the slave population, establish Catholicism as the island's religion, punish deserting soldiers, and maintain stability. ${ }^{28}$ Members of the Spanish elite were able to avoid or appeal death sentences, unlike native Puerto Ricans, who categorically opposed capital punishment. ${ }^{29}$ This opposition continued after the United States annexed Puerto Rico from Spain in 1898. ${ }^{30}$

Eventually, the Puerto Rico Legislature abolished the death penalty in $1929 .{ }^{31}$ When Puerto Rico ratified its own Constitution in 1952, it included a Bill of Rights, which stated in relevant part that "[t]he Death Penalty shall not exist." 32 Many have construed Puerto Rico's adoption of its own Constitution as an act of "popular sovereignty" in which the Commonwealth exercised "a

27. Transcript of Oral Argument at 3, Puerto Rico v. Sanchez Valle, 579 U.S. _ (2016) (No. 15-108).

28. Cristina M. Quiñones-Betancourt, Note, When Standards Collide: How the Federal Death Penalty Fails the Supreme Court's Eighth Amendment Evolving Standards of Decency Test When Applied to Puerto Rican Federal Capital Defendants, 23 CoRnell J.L. \& PuB. POL’Y 157, 178 (2013).

29. Id. at 179 .

30. Id.

31. Id. at 180 .

32. P.R. CONST art. II, $\S 7$. 
degree of autonomy and independence normally associated with States of the Union." 33

For instance, in the aforementioned Castro Garcia case, the Supreme Court of Puerto Rico found that Puerto Rico and the United States were separate sovereigns because of the "doctrine of popular sovereignty ... identified by Alexis de Tocqueville as the defining characteristic of American constitutionalism." ${ }^{34}$ In 1987, the First Circuit similarly ruled in United States v. López Andino $^{35}$ that Puerto Rico was a separate sovereign for Double Jeopardy purposes "because its criminal laws emanate from 'the people of Puerto Rico,' who engaged in an exercise of popular sovereignty in 1952 by 'organiz[ing] a government pursuant to a constitution of their own adoption." 36

This concept of popular sovereignty, however, was challenged in the wake of Congress's 1994 passage of the Federal Death Penalty Act (FDPA). ${ }^{37}$ The FDPA greatly expanded the number of federal crimes that were death-eligible. ${ }^{38}$ Subsequently, in 1997 , Representative Jorge de Castro submitted a resolution in the Puerto Rican legislature asking the Attorney General to declare Puerto Rico exempt from any application of the death penalty. ${ }^{39}$ Meanwhile, Reverend Moses Rosa noted "both the Catholic and Protestant churches have strongly opposed the death penalty throughout the last century." ${ }^{0}$ That said, "members of the ruling New Progressive Party, which seeks statehood for Puerto Rico, claim[ed] that the Puerto Rican constitution is a federal

33. United States v. Lopez Andino, 831 F.2d 1164, 1168 (1st Cir. 1987).

34. Puerto Rico v. Castro Garcia, 120 D.P.R. 740, 787 n.4 (P.R. 1988).

35. 831 F.2d 1164 (1st Cir.1987).

36. Diaz Morales v. Commonwealth of Puerto Rico, No. 15-1096, 2015 WL 4742512 at *7 (D.P.R. 2015) (quoting United States v. López Andino, 831 F.2d 1164, 1168, 1172 (1st Cir.1987)).

37. 18 U.S.C. $\S \S 3591-3598$ (2012).

38. See Kennedy v. Louisiana, 554 U.S. 407, 423 (2008) (discussing the wide reach of the FDPA).

39. See Puerto Rico and the Death Penalty, Death Penalty Info. Ctr. [hereinafter Puerto Rico], http://www.deathpenaltyinfo.org/node/881 (last visited May 30, 2016) (detailing the history of the death penalty in Puerto Rico) (on file with the Washington and Lee Law Review).

40. Id. 
document and that there is nothing to prevent federal imposition of capital punishment in the territory." 41

This conflict later played out in the courtroom when, in early 2000, the U.S. Attorney General authorized the U.S. Attorney for the District of Puerto Rico to seek the death penalty against defendants Joel Rivera Alejandro and Hector Oscar Acosta Martinez in the event of a conviction. ${ }^{42}$ Rivera Alejandro and Acosta Martinez were charged with, inter alia, firearm murder in relation to a crime of violence (18 U.S.C. § 924(j)) and killing a person in retaliation for providing law enforcement officials with information relating to the possible commission of a federal offense (18 U.S.C. $§ 1513(\mathrm{a})(1)(B)) .{ }^{43}$ Both of these crimes were death-eligible under the FDPA. ${ }^{44}$

Cristina Gutierrez, a Baltimore criminal defense attorney, was appointed as lead counsel in the case and submitted a brief arguing that the FDPA was inapplicable in Puerto Rico. ${ }^{45}$ In an opinion issued on July 17, 2000, the United States District Court for the District of Puerto Rico agreed with her. ${ }^{46}$ In United States $v$. Acosta Martinez, the court found that:

The notion of popular sovereignty not only undergirds the [Federal] Constitution.... it is also embodied in the Commonwealth Constitution approved by Congress, both in the Preamble ("We [the people of Puerto Rico] understand that the democratic system of government is one in which the will of the people is the source of public power...."), and in Article I ("[The Commonwealth's political power emanates from the people and shall be exercised in accordance with their will, within the terms of the compact agreed upon between the people of Puerto Rico and the United States of

41. Id.

42. United States v. Acosta Martinez, 106 F.Supp.2d 311, 312 (D.P.R. 2000).

43. $I d$.

44. Id.

45. See Colin Miller, Is Cristina Gutierrez Responsible for the Death Penalty in Puerto Rico?, EvidenceProf Blog (July 29, 2015) [hereinafter Gutierrez], http://lawprofessors.typepad.com/evidenceprof/2015/07/is-cristina-gutierrezresponsible-for-the-death-penalty-in-puerto-rico.html (last visited May 28, 2016) (explaining the facts surrounding the Acosta-Martinez case, and Gutierrez's failure to file an appellate brief in the appeal to the First Circuit) (on file with the Washington and Lee Law Review).

46. Acosta Martinez, 106 F.Supp.2d at 311. 
America.]"). Moreover, in approving the Constitution of the Commonwealth, the Constituent Convention expressed that upon the Constitution becoming effective, the people of Puerto Rico would be "organized in a commonwealth established within the terms of the compact entered into by mutual consent, which is the basis of our union with the United States of America." 47

Perhaps wary of the fact that it was largely making a political argument, the court tried to frame its opinion as a legal certainty: "Although the final determination of the status of Puerto Rico is a political question for the Congress and the people of Puerto Rico to decide, the applicability of the federal death penalty in the Commonwealth, under the present constitutional arrangement, is not." 48 According to the court, the United States government was claiming that the death penalty applies to Puerto Rico citizens who are deprived of the indirect or direct opportunity to participate in the government that authorizes the death penalty. ${ }^{49}$ As such, the court held that the federal government's action "shocks the conscience" and violated Puerto Ricans' rights to substantive due process. ${ }^{50}$

The court also wondered how Puerto Rican citizens could be tried under federal death penalty machinery for crimes committed solely within the Commonwealth "while at the same time denying them a say in the political process of the government that tries them." 51 Ultimately, the court found that capital punishment could only be imposed "on the consent of those whose rights may be affected by its imposition, such consent expressed through their participation in the political process as a manifestation of their free will." ${ }^{2}$

The United States thereafter appealed to the First Circuit. An attorney for Rivera Alejandro and a couple of amici filed briefs in support of the district court's opinion. ${ }^{53}$ The lead attorney on

\footnotetext{
47. Id. at 323 .

48. Id. at 325 .

49. Id. at 326-27.

50. Id.

51. Id. at 327 .

52. Id.

53. See generally Brief of Appellee, United States v. Acosta-Martinez, No. 00-2088, 2001 WL 36025318 (1st Cir. 2001); Brief of the Commonwealth of
} 
the case, however, did not file a brief. ${ }^{54}$ In early 2001, Cristina Gutierrez had contracted multiple sclerosis, was on the brink of having a record number of client complaints brought against her, and had been fired and sued by her own law firm. ${ }^{55}$ On March 28, 2001, a default order was sent to Gutierrez's law firm, with that order being returned to the court by FedEx a few days later along with the note, "REFUSED-CO GOING OUT OF BUSINESS." 56

Without the benefit of a brief from the lead attorney, the First Circuit reversed the district court's opinion and found the FDPA applied in Puerto Rico. ${ }^{57}$ In doing so, the First Circuit rejected the concept of popular sovereignty: "The creation of the Commonwealth granted Puerto Rico authority over its own local affairs; however, 'Congress maintains similar powers over Puerto Rico as it possesses over the federal states." 58 The court then found that Congress exercised that intent by passing the FDPA with the clear intent that it apply to crimes committed in Puerto Rico. 59

The First Circuit proceeded to find that the exercise of these powers did not "shock the conscience" and thus violate the Due Process Clause. ${ }^{60}$ Instead, the court noted that it had previously enforced a variety of Congressional statutes in Puerto Rico, including OSHA, the Clean Water Act, and the Defense Base Act. ${ }^{61}$

Puerto Rico as Amicus Curiae in Support of Petitioners, Acosta-Martinez v. United States, No. 01-7137, 2001 WL 34117193 (2001); Brief of Amici Curiae, Comisión De Derechos Civiles De Puerto Rico, Ciudadanos Contra La Pena De Muerte, Colegio De Abogados De Puerto Rico in Support of Petitioners, AcostaMartinez v. United States, No. 01-7137, 2002 WL 32135733 (2002).

54. See Gutierrez, supra note 45 ("Acosta-Martinez's appellate brief was due in March 2001. Gutierrez failed to file this brief. ... As a result, the lead defendant in the case did not have his own brief.").

55. See id. (describing the events that led to Gutierrez failing to file a brief).

56. Id.

57. See United States v. Acosta Martinez, 252 F.3d 13, 21 (1st Cir. 2001) (ruling that "the death penalty notice is reinstated").

58. Id. at 18 (quoting United States v. Quinones, 758 F.2d 40, 43 (1st Cir.1985)).

59. See id. at 20 (discussing several "indicia of congressional intent to apply the death penalty to Puerto Rico").

60. Id.

61. Id. 
The court closed its opinion with the quote that led this essay, noting that Congress has the authority to "apply the federal criminal laws to Puerto Rico," "set the penalties for violations of those laws," and afford Puerto Rican citizens "the protection of the federal criminal laws." 62 According to the First Circuit, "[t]he argument made by defendants and amici is a political one, not a legal one." 63 In other words, while popular sovereignty might be a popular political claim, it is not a legally cognizable one.

The First Circuit's decision prompted protests in Puerto Rico, with Puerto Rican Bar Association President Arturo Luis Davila Toro noting, "[w]e don't believe in capital punishment, and they are trying to impose it on us." 64 Ultimately, Rivera Alejandro and Acosta Martinez were acquitted by a Puerto Rican jury in $2003 .{ }^{65}$ It is not "clear whether questions about the federal government's right to have jurisdiction in the case affected their decision." 66 Acosta Martinez has never been overturned, but Puerto Rican juries have refused to impose the death penalty in all subsequent cases in which the federal government has brought FDPA prosecutions on the island. ${ }^{67}$

62. Id.

63. Id.

64. Death Penalty, supra note 39.

65. See Abby Goodnough, Acquittal in Puerto Rico Averts Fight Over Government's Right to Seek Death Penalty, N.Y. Times (Aug. 1, 2003), http://www.nytimes.com/2003/08/01/us/acquittal-puerto-rico-averts-fight-overgovernment-s-right-seek-death-penalty.html (last visited May 30, 2016) (describing how jurors acquitted two defendants in a federal death penalty case, elating many Puerto Ricans who believe the death penalty betrays their "culture and constitution, which outlaws capital punishment") (on file with the Washington and Lee Law Review).

66. Id.

67. See Jury Declines to Impose Death Penalty in Puerto Rico Murders, REUTERS (Mar. 23, 2013), http://www.reuters.com/article/us-usa-deathpenaltypuertorico-idUSBRE92N02020130324 (last visited May 29 2016) ("The jury failed to reach a unanimous decision on a death sentence ....") (on file with the Washington and Lee Law Review). 


\section{The Tenth Amendment and Dual Sovereignty}

The Commonwealth of Puerto Rico claimed in Sanchez Valle that the Double Jeopardy Clause does not preclude successive federal and Commonwealth prosecutions "because Commonwealth law and Federal law emanate from different sources of authority: The people of Puerto Rico on the one hand and Congress on the other." 68 This invocation of the concept of popular sovereignty is appealing on a certain level, and the United States District Court for the District of Puerto Rico similarly relied upon it in finding that the FDPA could not be applied in Puerto Rico. ${ }^{69}$

The First Circuit, however, overturned that conclusion, finding, inter alia, that "it would be anomalous for Congress to grant the people of Puerto Rico American citizenship and then not afford them the protection of the federal criminal laws." 70 Given that the Double Jeopardy Clause is a long established federal criminal law ${ }^{71}$ the easy conclusion to draw would be that Puerto Rican citizens are thus entitled to its protections. After all, how can Puerto Rico be a dual sovereign for Double Jeopardy purposes but a dependent sovereign for FDPA purposes?

The obvious response to this argument is the fact that the FDPA applies even in states that have abolished the death penalty, ${ }^{72}$ despite the fact that citizens in those states can be prosecuted successively in federal and state court. ${ }^{73}$ Therefore, for instance, a New York resident could conceivably be (1) prosecuted

68. Transcript of Oral Argument, at 3, Puerto Rico v. Sanchez Valle, 579 U.S. _ (2016) (No. 15-108).

69. See supra notes 47-52 and accompanying text (discussing Acosta Martinez).

70. United States v. Acosta Martinez, 252 F.3d 13, 21 (1st Cir. 2001).

71. See, e.g., United States v. Hans, 548 F. Supp. 1119, 1124 (S.D. Ohio 1982) ("Collateral estoppel, long established as a rule of federal criminal law, was expressly incorporated into the scope of Fifth Amendment double jeopardy protections by the Supreme Court in Ashe v. Swenson.").

72. See generally Joshau Herman, Comment, Death Denies Due Process: Evaluating Due Process Challenges to the Federal Death Penalty Act, 53 DePAUL L. REV. 1777 (2004) (discussing the application of the FDPA to the several states).

73. See supra note 15 and accompanying text (detailing the Double Jeopardy Clause). 
in state and federal court successively; and (2) given the death penalty under the FDPA even though New York abolished the death penalty.

The dual sovereignty doctrine explains both of these outcomes. In turn, the Tenth Amendment explains the dual sovereignty doctrine. The Tenth Amendment provides that "[t]he powers not delegated to the United States by the Constitution, nor prohibited by it to the states, are reserved to the states respectively, or to the people." ${ }^{4}$ The Supreme Court has referred to the Tenth Amendment as an explicit dual sovereignty provision $^{75}$ and noted that Congressional statutes are unconstitutional if they "violate[] the principles of dual sovereignty embodied in the Tenth Amendment."76

For instance, in New York $v$. United States, ${ }^{77}$ the Supreme Court held that Congress violated the Tenth Amendment by compelling New York into administering the "take title" provisions of the Low-Level Radioactive Waste Policy Amendments Act of $1985 .{ }^{78}$ Similarly, in Printz v. United States, ${ }^{79}$ the Supreme Court found a Tenth Amendment violation when Congress sought to compel state officials to perform background checks under the Brady Handgun Violence Prevention Act. ${ }^{80}$

The defendant in United States $v$. Tavares ${ }^{81}$ tried to raise a similar argument after he was given a death sentence under the FDPA. ${ }^{82}$ This claim failed, but not because New York lacked the ability to make a Tenth Amendment objection; instead, the court noted that "[n]o official of the State of New York has objected to assisting the federal government in killing persons condemned to death in a federal criminal proceeding." 83 In rejecting a similar Tenth Amendment challenge in United States $v$. Henderson, ${ }^{84}$ the

74. U.S. Const. amend. X.

75. Printz v. United States, 521 U.S. 898, 923 n.13 (1997).

76. Pierce County, Wash. v. Guillen, 537 U.S. 129, 148 n.10 (2003).

77. 505 U.S. 144 (1992)

78. Id. at 188 .

79. 521 U.S. 898.

80. Id. at 935 .

81. No. 04-CR-156 JBW, 2006 WL 473773 (E.D.N.Y. Feb. 28, 2006).

82. Id. at *5.

83. Id. at *6.

84. 485 F.Supp.2d 831 (S.D. Ohio 2007). 
United States District Court for the Southern District of Ohio concluded "that dual sovereignty exists in this case, and the United States, with the State of Ohio's blessing, may exercise its sovereignty in this matter." 85

These cases illustrate how the dual sovereignty doctrine is defined by the Tenth Amendment. ${ }^{86}$ The FDPA applied to a New York citizen because no official in New York objected, and the FDPA applied to an Ohio citizen because Ohio gave its blessing. Conversely, if officials in either of these states objected, the FDPA might have failed a Tenth Amendment challenge, like the Acts in New York and Printz. This is because states and the federal government are dual sovereigns, meaning that the former can use the Tenth Amendment to challenge Congressional attempts to compel state officials into administering federal programs.

Conversely, as the First Circuit's opinion in Acosta Martinez makes clear, Puerto Rico lacked the authority to challenge application of the FDPA in the Commonwealth. ${ }^{87}$ This make sense given that the First Circuit has concluded that "[t]he limits of the Tenth Amendment do not apply to Puerto Rico, which is 'constitutionally a territory' ... because Puerto Rico's powers are not '[those] reserved to the States' but those specifically granted to it by Congress under its constitution." 88

This takes us back to the "crucial determination" under the dual sovereignty doctrine, which focuses upon "whether the two entities draw their authority to punish the offender from distinct sources of power." ${ }^{89}$ As the above language makes clear, Puerto Rico's authority to punish offenders is "specifically granted to it by Congress," 90 meaning that it is not a dual sovereign for Double Jeopardy purposes. Indeed, soon after the Supreme Court of Puerto Rico decided Sanchez Valle, the United States District

85. Id. at 859 .

86. In re City of Harrisburg, PA, 465 B.R. 744, 753 (Bankr. M.D.Pa. 2011).

87. See supra notes 60-63 and accompanying text (discussing Acosta Martinez).

88. Franklin California Tax-Free Trust v. Puerto Rico, 805 F.3d 322, 34445 (1st Cir. 2015) (quoting United States v. Lopez Andino, 831 F.2d 1164, 1172 (1st Cir. 1987) (Torruella, J., concurring))..

89. Heath v. Alabama, 474 U.S. 82, 88 (1985).

90. U.S. Const. amend. X. 
Court for the District of Puerto Rico issued its opinion in Diaz Morales v. Commonwealth of Puerto Rico, ${ }^{91}$ concluding "that the Tenth Amendment does not apply to the Commonwealth and that the same is not a dual sovereign for double jeopardy purposes."92

\section{Conclusion}

In Sanchez Valle, the Commonwealth argued that the concept of popular sovereignty makes Puerto Rico a dual sovereign whose authority to enforce criminal laws emanates from the Puerto Rican people. If this argument held water, Puerto Rico would have been able to challenge the attempt to impose the FDPA on its citizens. The Commonwealth, however, was not able to do so because the Tenth Amendment does not apply to Puerto Rico, meaning that it is not a dual sovereign to the federal government. As such, the dual sovereignty doctrine does not apply to Puerto Rico, and the Double Jeopardy Clause does prevent successive prosecutions in federal court and the Commonwealth.

91. No. 15-1096, 2015 WL 4742512 (D.P.R., Aug. 11, 2015).

92. Id at * 1 . 